(Supporting Information)

\title{
Supramolecular Helical Assembly of an Achiral Cyanine Dye in an Induced Helical Amphiphilic Poly(phenylacetylene) Interior in Water
}

Toyoharu Miyagawa ${ }^{\dagger}$ Miho Yamamoto, ${ }^{\ddagger}$ Reiko Muraki, ${ }^{\ddagger}$ Hisanari Onouchi, ${ }^{\dagger,}$ and Eiji Yashima ${ }^{* \dagger, *}$

${ }^{\dagger}$ Yashima Super-structured Helix Project, Exploratory Research for Advanced Technology (ERATO), Japan Science and Technology Agency (JST), 101 Creation Core Nagoya, 2266-22 Anagahora, Shimoshidami, Moriyama-ku, Nagoya 463-0003, Japan. ${ }^{*}$ Department of Molecular Design and Engineering, Graduate School of Engineering, Nagoya University, and ${ }^{\S}$ Venture Business Laboratory (VBL), Nagoya University, Chikusa-ku, Nagoya 464-8603, Japan.

\section{Materials and Instruments}

Materials. Cis-transoidal, stereoregular poly-1 was prepared according to the previously reported method. ${ }^{1}$ The number-average molecular weight $\left(M_{\mathrm{n}}\right)$ and its distribution $\left(M_{\mathrm{w}} / M_{\mathrm{n}}\right)$ were $2.1 \times 10^{4}$ and 4.1 , respectively, as determined by size exclusion chromatography (SEC) with tetrahydrofuran (THF) containing $0.1 \mathrm{wt} \%$ tetran-butyl ammoniumbromide as the eluent. Cyanine dyes, 3,3'-diethyloxadicarbocyanine iodide $\quad(\mathbf{O}-5), \quad 3,3$ '-diethyloxatricarbocyanine iodide $\quad(\mathbf{O}-7), \quad$ 1,1',3,3,3',3'hexamethylindodicarbocyanine iodide (I-5), and 3,3'-diethylthiadicarbocyanine iodide (S-5), were purchased from Acros Organics (Geel, Belgium). 3,3'Diethyloxacarbocyanine iodide (O-3), 1,1'-diethyl-2,2'-dicarbocyanine iodide (Q-5), and L- and D-tryptophan (L- and D-Trp) (purity >98\%) were obtained from Aldrich (Milwaukee, WI). (1R,2S)-(-)- and $(1 S, 2 R)-(+)-$ norephedrine $((1 R, 2 S)$ - and $(1 S, 2 R)-2)$ and anhydrous methanol (water content $<0.005$ vol \%) were purchased from Wako Chemicals (Osaka, Japan).

Instruments. NMR spectra were taken on a Varian VXR-500S $\left(500 \mathrm{MHz}\right.$ for $\left.{ }^{1} \mathrm{H}\right)$ spectrometer in $\mathrm{D}_{2} \mathrm{O}$ or $\mathrm{CD}_{3} \mathrm{OD}$ using a solvent residual peak as the internal standards. SEC measurement was performed with a Jasco PU-1580 liquid chromatograph 
equipped with a UV detector (254 nm; Jasco UV-1570). A Tosoh (Tokyo, Japan) TSKgel Multipore- $\mathrm{H}_{\mathrm{XL}}-\mathrm{M}$ SEC column $(30 \mathrm{~cm})$ was connected, and THF containing 0.1 wt $\%$ tetra- $n$-butylammonium bromide was used as the eluent at a flow rate of 1.0 $\mathrm{mL} / \mathrm{min}$. The molecular weight calibration curve was obtained with polystyrene standards (Tosoh). The absorption and CD spectra were measured in a $0.5-$, or $1.0-\mathrm{mm}$ quartz cell on a Jasco V-570 spectrophotometer and a Jasco J-725 or J-820 spectropolarimeter, respectively. The temperature was controlled with a Jasco ETC $505 \mathrm{~T}$ (for absorption measurements) and a Jasco PTC-423L apparatus (for CD measurements). The $\mathrm{pH}$ of the solution was measured with a B-212 $\mathrm{pH}$ meter (Horiba, Japan). $\mathrm{pD}$ values were estimated from the reading of $\mathrm{pH}$ meter according to the equation $\mathrm{pD}=\mathrm{pH}_{\text {meter reading }}+0.40$ reported by Glasoe et al. ${ }^{2}$

\section{Inclusion Complexation of Cyanine Dyes with Poly-1 in Water}

Deionized, distilled water was distilled again under nitrogen before use for all experiments. The concentration of poly-1 was calculated on the basis of the monomer units. A typical experimental procedure for the inclusion experiments of cyanine dyes by poly-1 in water is described below.

Stock solutions of $\mathbf{0 - 5}(2.7 \mathrm{mg}, 5.6 \mu \mathrm{mol})$ in methanol and poly-1 (2.0 $\mathrm{mg}, 5.1$ $\mu \mathrm{mol})$ in water were prepared in 5- and 1-mL flasks with stopcocks, respectively. A 116 $\mu \mathrm{L}$ aliquot of the stock solution of $\mathbf{0 - 5}(0.13 \mu \mathrm{mol})$ was placed into a $2-\mathrm{mL}$ vessel equipped with a screwcap using a micropipette (Mettler-Toledo $\mathrm{GmbH}$, Switzerland) and the solvent was evaporated by flushing with nitrogen gas. A $250 \mu \mathrm{L}$ aliquot of the stock solution of poly-1 and water $(189 \mu \mathrm{L})$ were transferred to the vessel and the resulting mixture was immediately mixed using a vibrator (Iuchi, Japan). An eleven $\mu \mathrm{L}$ aqueous $0.46 \mathrm{M} \mathrm{HClO}_{4}$ was then added to the vessel. The absorption spectra of the mixture before (neutral) and after the addition of aqueous $\mathrm{HClO}_{4}$ (acidic) were taken using a $0.5-\mathrm{mm}$ quartz cell (c and $\mathrm{d}$ in Figure 2 ). The solution color gradually changed 
from pink to turquoise blue, accompanied by a large red shift in the absorption up to ca. $90 \mathrm{~nm}$ due to the J-aggregates formation of O-5. The absorption spectra of $\mathbf{0 - 5}$ in the absence of poly-1 in neutral and acidic water were also measured; $\mathbf{0 - 5}$ is readily soluble in neutral water, but aggregated in acidic water $(\mathrm{pH} 2.1)$ and then immediately precipitated, so that the absorption spectrum of 0-5 in acidic water was measured after filtration ( $a$ and $b$ in Figure 2).

The inclusion experiments of the other cyanine dyes $\mathbf{O}-\mathbf{3}, \mathbf{O}-\mathbf{7}, \mathbf{I}-\mathbf{5}, \mathbf{S}-\mathbf{5}$, and Q-5 were also performed in a similar way described above in the absence or presence of poly-1. The changes in the absorption spectra of the cyanine dyes with and without poly-1 in neutral and acidic water are shown in Figure S1.

\section{Chiral J-Aggregates Formation of O-5 in a Helical Poly-1 Interior}

The chiral J-aggregates of $\mathbf{0 - 5}$ formed in a one-handed helical poly-1 interior induced by D- and L-Trp, and $(1 R, 2 S)$ - and $(1 S, 2 R)-2$ were prepared in acidic water. A typical experimental procedure is described below.

Stock solutions of D- and L-Trp $(128 \mathrm{mg}, 0.627 \mathrm{mmol})$ in aqueous $0.21 \mathrm{M} \mathrm{HClO}_{4}$ were prepared in 3-mL flasks with stopcocks, respectively. The mixture of $\mathbf{0 - 5}$ and poly-1 in neutral water was prepared in the same way as described above and cooled in an ice bath. A $61 \mu \mathrm{L}$ aliquot of the stock solution of D- or L-Trp and aqueous $0.46 \mathrm{M}$ $\mathrm{HClO}_{4}(11 \mu \mathrm{L})$ were then added in this order to the vessel and the solution was allowed to warm to room temperature for $220 \mathrm{sec}$, since the absorption intensity at $669 \mathrm{~nm}$ of the mixture due to the $\mathrm{J}$-aggregate formation of $\mathbf{0 - 5}$ reached a maximum value during the time period, and gradually decreased with time at room temperature (Figure S5).

Although the 0-5 aggregates showed almost no ICD in the chromophore region at this stage, extraordinary intense ICDs appeared in the $\mathbf{0 - 5}$ chromophore regions after annealing the samples at $55{ }^{\circ} \mathrm{C}$ for 90 (Trp) or $60 \mathrm{sec}(2)$, followed by cooling in an ice bath for $60 \mathrm{sec}$ (a and $\mathrm{b}$ in Figure 3). The ICD intensity in the 0-5 aggregate regions 
was sensitive to the heating temperature and time, and the $\mathrm{HClO}_{4}$ concentration, and the optimized conditions were determined by screening these parameters; for the effects of the heating temperature and time, and the $\mathrm{HClO}_{4}$ concentration on the ICD intensities of the chiral J-aggregated $\mathbf{0 - 5}$ in the presence of a helical poly-1 induced by L-Trp and $(1 R, 2 S)-2$, see Figures S6-S8.

Effect of pH. The chiral J-aggregates of O-5 induced by a one-handed helical poly$\mathbf{1}$ assisted by D-Trp and $(1 R, 2 S)-\mathbf{2}$ were prepared in acidic water in the same way as described above ( $\mathrm{a}$ in Figures 4A and 4B). To these were added an increasing amount of aqueous $\mathrm{NaOH}(0.5$ or $2 \mathrm{~N})$ and the $\mathrm{CD}$ and absorption spectra were measured (Figure 4).

CD and Absorption Spectral Changes of Chiral J-Aggregates of O-5 During the Helix-Sense Inversion of the Template Poly-1. A typical experimental procedure is described below.

Stock solutions of $\mathbf{O - 5}(3.0 \mathrm{mg}, 6.2 \mu \mathrm{mol})$ in methanol, poly-1 $(2.0 \mathrm{mg}, 5.1 \mu \mathrm{mol})$ in water, and D- or L-Trp (128 mg, $0.627 \mathrm{mmol})$ in aqueous $0.21 \mathrm{M} \mathrm{HClO}_{4}$, were prepared in 5-, 1-, and 3-mL flasks with stopcocks, respectively. A $104 \mu \mathrm{L}$ aliquot of the stock solution of $\mathbf{0 - 5}(0.12 \mu \mathrm{mol})$ was placed into a $2-\mathrm{mL}$ vessel equipped with a screwcap using a micropipette and the solvent was evaporated by flushing with nitrogen gas. A $250 \mu \mathrm{L}$ aliquot of the stock solution of poly-1 and water $(196 \mu \mathrm{L})$ were transferred to the vessel and the resulting mixture was immediately mixed using a vibrator and cooled in an ice bath. After a $30 \mu \mathrm{L}$ aliquot of the stock solution of D-Trp and aqueous $0.46 \mathrm{M}$ $\mathrm{HClO}_{4}(20 \mu \mathrm{L})$ were added in this order to the vessel, the solution was allowed to warm to room temperature for $220 \mathrm{sec}$. The color of the solution became turquoise blue during this procedure. The solution was then heated in a $55^{\circ} \mathrm{C}$ water bath for $90 \mathrm{sec}$ and then cooled in an ice bath for $1 \mathrm{~min}$. After the initial $\mathrm{CD}$ and absorption spectra were measured, a $30 \mu \mathrm{L}$ aliquot of the stock solution of L-Trp was added to the solution and the absorption and CD spectra were immediately measured. This gave a poly-1-0-5 
complex with a racemic $\operatorname{Trp}([\mathrm{L}-\operatorname{Trp}] /[\mathrm{D}-\operatorname{Trp}]=1 / 1(\mathrm{~mol} / \mathrm{mol}))$. Further addition of a 30 $\mu \mathrm{L}$ of the L-Trp solution $([\mathrm{L}-\operatorname{Trp}] /[\mathrm{D}-\operatorname{Trp}]=2 / 1(\mathrm{~mol} / \mathrm{mol}))$ was done before the absorption and CD measurements (Figure 5A). The same helicity inversion experiments were also performed for poly-1- L-Trp in acidic water (Figure S10A) and poly1-(1R,2S) and - (1S,2R)-2 in acidic and weak alkaline water (Figures 5B and S10B).

\section{Molecular Modeling and Calculations}

Molecular modeling and molecular mechanics calculations were conducted with the Dreiding force field (version 2.21) ) $^{3}$ as implemented in CERIUS ${ }^{2}$ software (version 3.8; Molecular Simulation Inc., Burlington, MA, USA) running on an Indigo ${ }^{2}$-Extreme graphics workstation (Silicon Graphics). The polymer model (20 repeating units of monomer units) of poly-1 was constructed using a Polymer Builder in CERIUS ${ }^{2}$. Achiral cyanine dye (O-5) was also constructed. Charges on atoms of poly-1 and $\mathbf{0 - 5}$ were calculated using charge equilibration (QEq) in CERIUS $^{2}$; total charges of the molecules were zero. The starting main chain conformation of a polymer model was defined as the double bond geometry (cis or trans) and a conformation of a rotational single bond. The double bond geometry was fixed to cis and the initial dihedral angle of a single bond from planarity was set to $150^{\circ}$ (transoid) based on the calculated righthanded helical structure of poly((4-carboxyphenyl)acetylene) ${ }^{4}$ The helix-sense of poly1 was tentatively assigned on the basis of the Cotton effect signs of the ICDs of analogous helical polyacetylene ${ }^{5}$ and their AFM measurement results. ${ }^{6}$ The constructed model (20 mer) was optimized by the smart minimizer (SM) method. The energy minimization was continued until the root-mean-square (rms) value became less than $0.1 \mathrm{kcal} \mathrm{mol}{ }^{-1} \AA^{-1}$. The average dihedral angle of the double bonds from planarity was $161.93 \pm 3.7^{\circ}$. The initial structure of $\mathbf{0 - 5}$ was also energy-minimized by the SM method. The optimized five $\mathbf{0 - 5}$ molecules were manually placed into the cavity of poly-1. The complex was further energy minimized by the SM method to relieve 
unfavorable van der Waals contacts. The average dihedral angle of the double bonds

from planarity for the optimized poly-1 complexed with $\mathbf{0 - 5}$ was $163.22 \pm 4.7^{\circ}$. The obtained helically twisted $\mathbf{0 - 5}$ aggregates aligned in the cavity of a helical poly-1 is shown in Figure 7.

\section{References and Notes}

(1) Nonokawa, R.; Yashima, E. J. Am. Chem. Soc. 2003, 125, 1278-1283.

(2) Glasoe, P. K.; Long, F. A. J. Phys. Chem. 1960, 64, 188-190.

(3) (a) Mayo, S. L.; Olafson, B. D.; Goddard III, W. A. J. Phys. Chem. 1990, 94, 8897-8909. (b) Rappé, A. K.; Goddard III, W. A. J. Phys. Chem. 1991, 95, $3358-3363$.

(4) Yashima, E.; Matsushima, T.; Okamoto, Y. J. Am. Chem. Soc. 1997, 119, $6345-6359$.

(5) Maeda, K.; Morino, K.; Okamoto, Y.; Sato, T.; Yashima, E. J. Am. Chem. Soc. 2004, 126, 4329-4342.

(6) (a) Sakurai, S.-i.; Okoshi, K.; Kumaki, J.; Yashima, E. Angew. Chem., Int. Ed. 2006, 45, 1245-1248. (b) Sakurai, S.-i.; Okoshi, K.; Kumaki, J.; Yashima, E. J. Am. Chem. Soc. 2006, 128, 5650-5651 

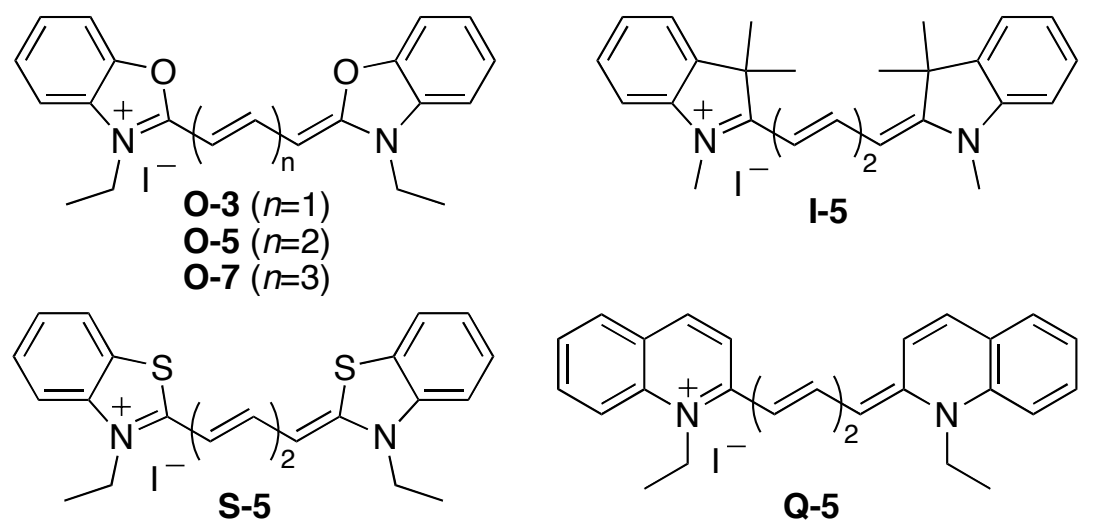

A: 0-3

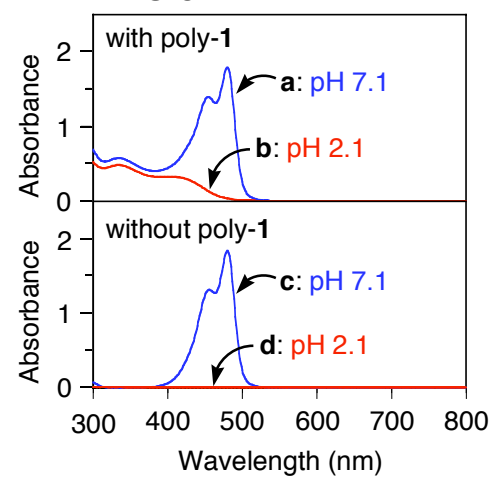

D: S-5

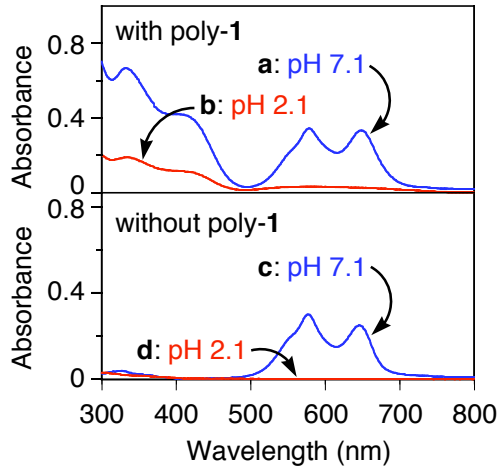

B: $0-7$

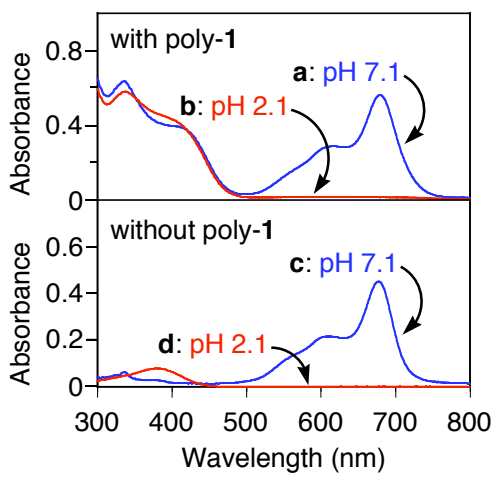

C: $1-5$

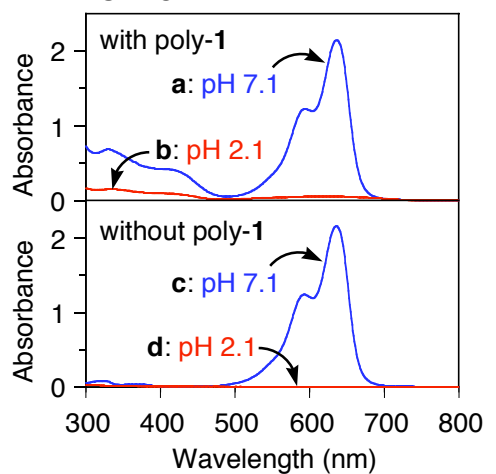

Figure S1. Absorption spectral changes of O-3 (A), O-7 (B), I-5 (C), S-5 (D), and Q-5 (E) in the presence ( $a$ and b) and absence ( $c$ and d) of poly-1 in neutral (a and c, blue lines, $\mathrm{pH}$ 7.1) and acidic water (b and d, red lines, $\mathrm{pH}$ 2.1). O-3, O-7, I-5, S-5, and Q-5 immediately precipitated at $\mathrm{pH} 2.1$ in the absence of poly-1, and the precipitates were removed by filtration before absorption measurements. All spectra were measured in a $0.5-\mathrm{mm}$ quartz cell at room temperature (ca. $\left.22-24{ }^{\circ} \mathrm{C}\right)$. [poly-1] $=1.0 \mathrm{mg} / \mathrm{mL}(2.6 \mathrm{mM}$ monomer unit), $[\mathrm{dye}]=0.26 \mathrm{mM}$, and $\left[\mathrm{HClO}_{4}\right]=0.020 \mathrm{M}$ (b and d). 


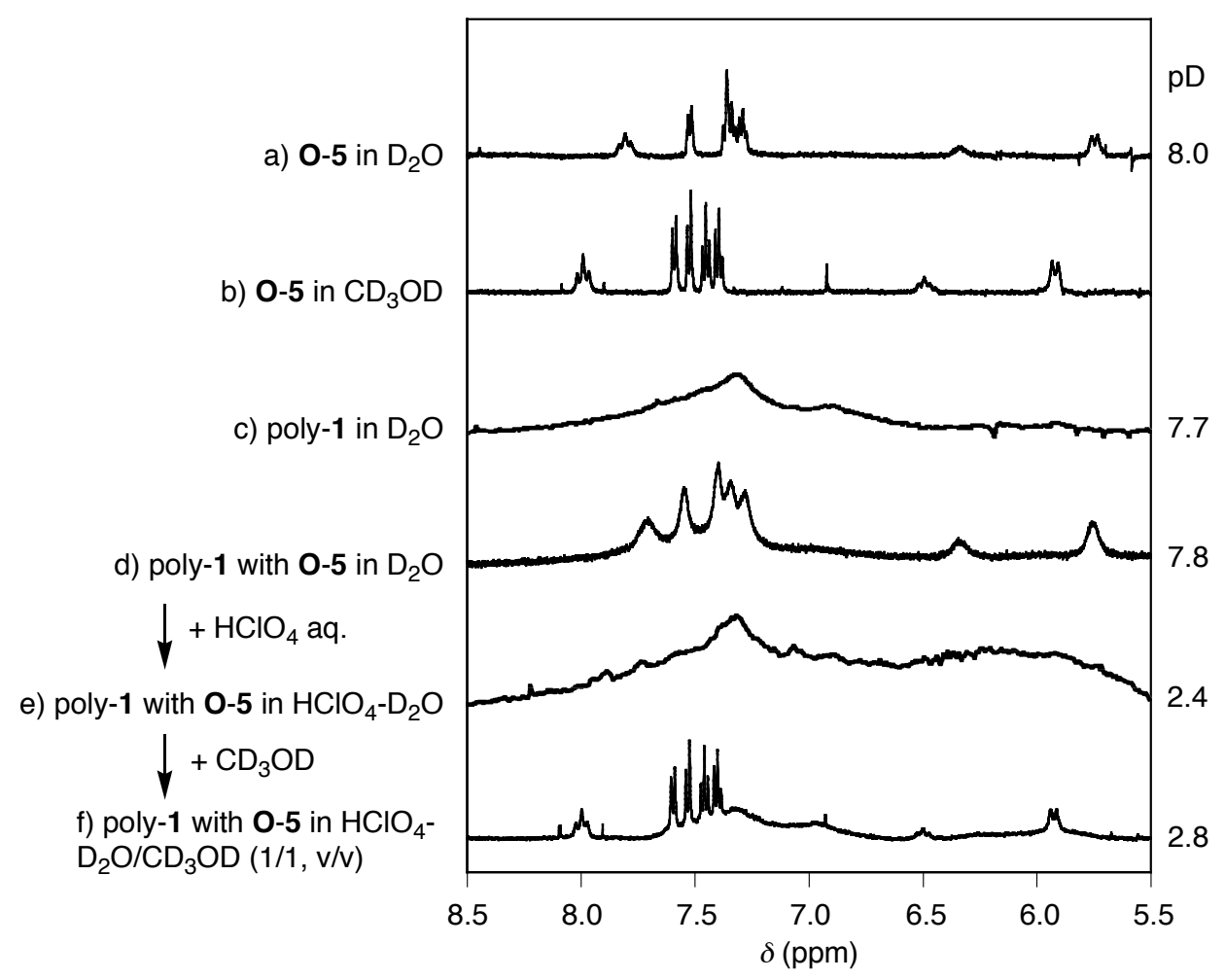

Figure S2. ${ }^{1} \mathrm{H}$ NMR spectra $\left(500 \mathrm{MHz}, 29{ }^{\circ} \mathrm{C}\right)$ of $\mathbf{O - 5}$ in $\mathrm{D}_{2} \mathrm{O}$ (a) and $\mathrm{CD}_{3} \mathrm{OD}(\mathrm{b})$, poly-1 in $\mathrm{D}_{2} \mathrm{O}$ (c), and poly-1 with $\mathbf{0 - 5}$ in $\mathrm{D}_{2} \mathrm{O}(\mathrm{d}), \mathrm{HClO}_{4}-\mathrm{D}_{2} \mathrm{O}$ (e), and $\mathrm{HClO}_{4}-$ $\mathrm{D}_{2} \mathrm{O} / \mathrm{CD}_{3} \mathrm{OD}(1: 1=\mathrm{v} / \mathrm{v})(\mathrm{f})$. [poly-1] $=1.0$ (c, d, and e) and $0.5 \mathrm{mg} / \mathrm{mL}(\mathrm{f}),[\mathbf{O}-5]=0.26$ (a, b, d, and e) and $0.13 \mathrm{mM}(\mathrm{f}),\left[\mathrm{HClO}_{4}\right]=0.026$ (e) and $0.013 \mathrm{M}(\mathrm{f})$. 

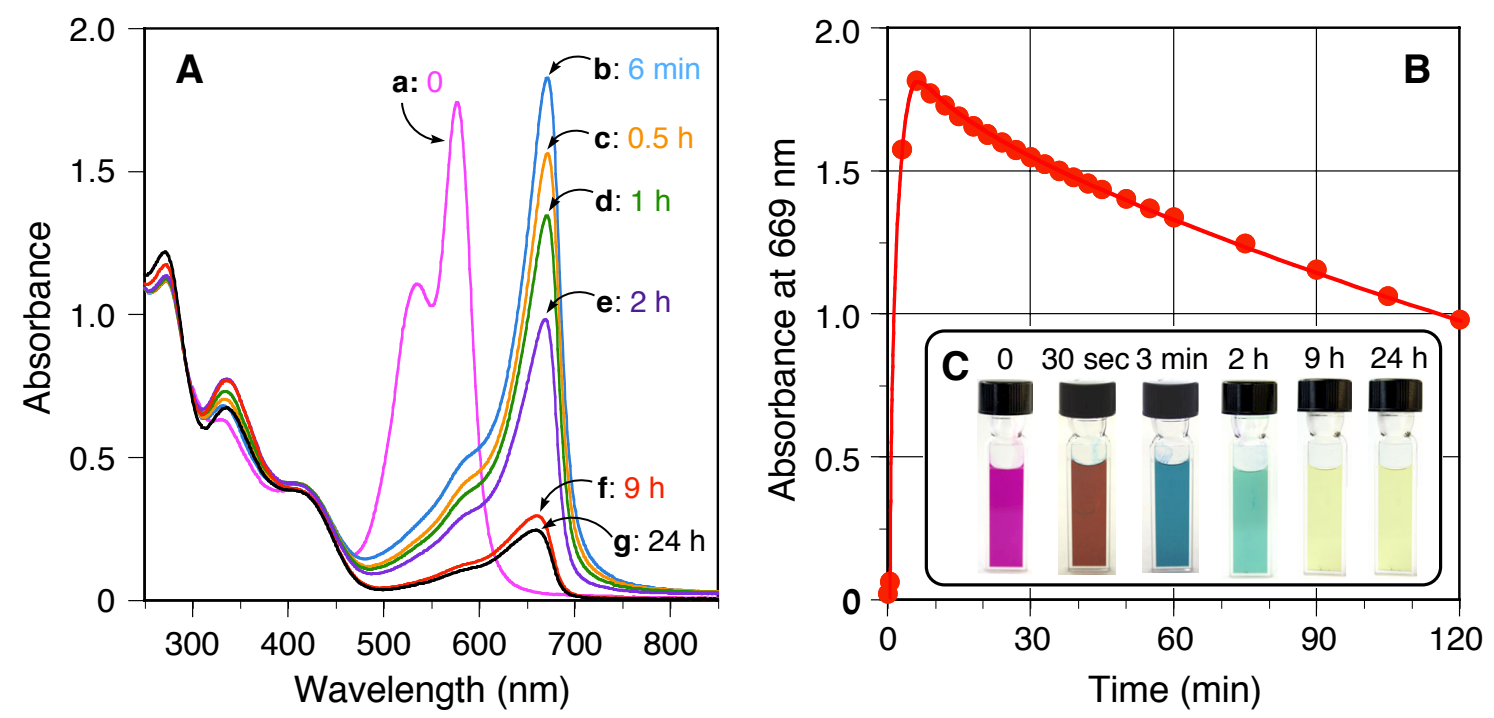

Figure S3. Absorption spectral changes (A), the plots of absorbance at $669 \mathrm{~nm}$ (B), and visible difference (C) of $\mathbf{O - 5}$ in the presence of poly-1 in acidic water $(\mathrm{pH} 2.1)$ with time. All spectra were measured in a $0.5-\mathrm{mm}$ quartz cell at room temperature (ca. $\left.22-25^{\circ} \mathrm{C}\right)$. [poly-1] $=1.0 \mathrm{mg} / \mathrm{mL}(2.6 \mathrm{mM}$ monomer unit $),[\mathbf{0}-5] /[$ poly-1 $]=0.1$, and $\left[\mathrm{HClO}_{4}\right]=0.020 \mathrm{M}$. 
Effect of $\mathrm{pH}$ on helicity induction in poly-1
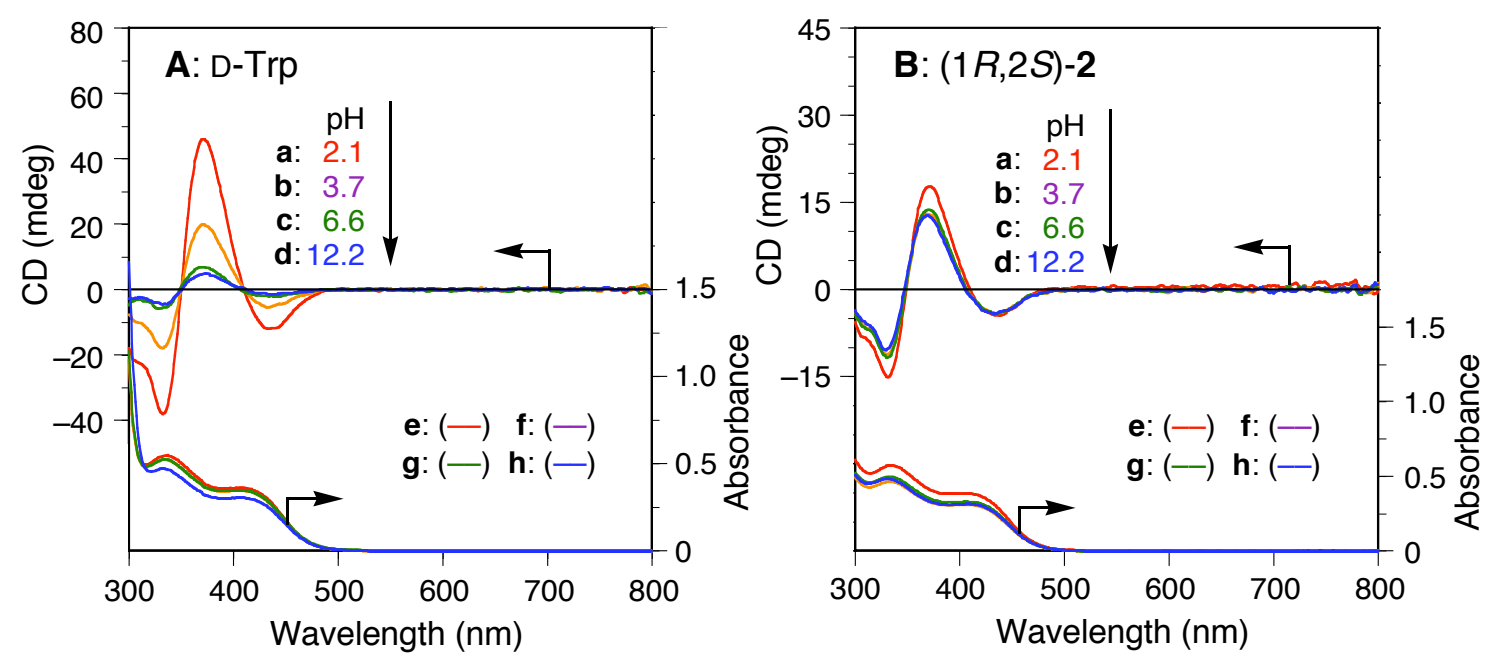

Figure S4. CD (a-d) and absorption spectral changes (e-h) of poly-1 with D-Trp (A) and $(1 R, 2 S)-2(\mathrm{~B})$ in the absence of $\mathbf{0 - 5}$ in acidic water upon the addition of aqueous $\mathrm{NaOH}$ at room temperature (ca. $25-26^{\circ} \mathrm{C}$ ). [poly-1] $=1.0 \mathrm{mg} / \mathrm{mL},[\mathbf{O}-\mathbf{5}] /[$ poly-1] $=0.1$, $[\mathrm{D}-\mathrm{Trp}] /\left[\right.$ poly-1] $=10$, and $\left[\mathrm{HClO}_{4}\right]_{0}=0.036(\mathrm{~A})$ and $0.20 \mathrm{M}(\mathrm{B})$. 
Effect of time on J-aggregates formation of $\mathbf{O - 5}$ in the presence of poly-1

and L-Trp or $(1 R, 2 S)-2$

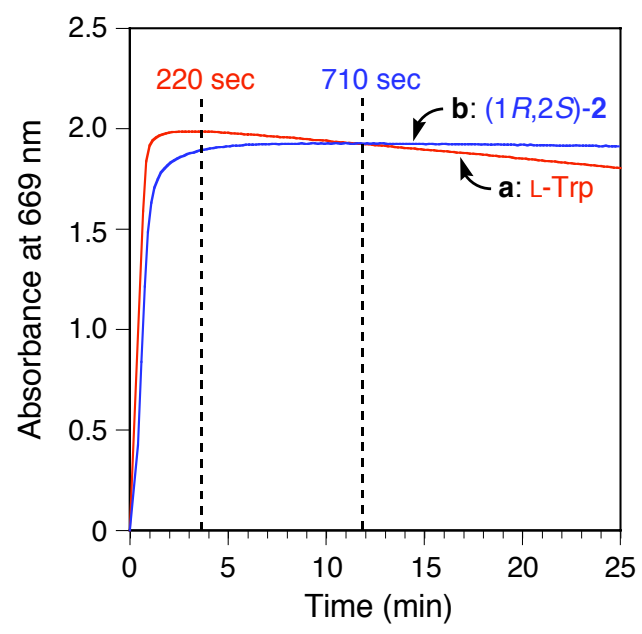

Figure S5. Changes in the absorbance at $669 \mathrm{~nm}$ corresponding to the J-aggregated $\mathbf{O}$ 5 chromophore upon the addition of L-Trp (a, red line) and (1R,2S)-2 (b, blue line) in the presence of poly-1 in acidic water $(\mathrm{pH} 2.1)$ at room temperature $\left(\mathrm{ca} .25^{\circ} \mathrm{C}\right)$ before annealing. All spectra were measured in a $0.5-\mathrm{mm}$ quartz cell. [poly-1] $=1.0 \mathrm{mg} / \mathrm{mL}$, $[\mathbf{O}-5] /[$ poly-1 $]=0.1,[\mathrm{~L}-\mathrm{Trp}] /\left[\right.$ poly-1] $=10,[(1 R, 2 \mathrm{~S})-\mathbf{2}] /[$ poly-1 $]=50,\left[\mathrm{HClO}_{4}\right]=0.025$ (a) and $0.20 \mathrm{M}$ (b). 
Effect of temperature on helical J-aggregates formation of $\mathbf{0 - 5}$ in the presence of helical poly-1 induced by L-Trp or $(1 R, 2 S)-2$
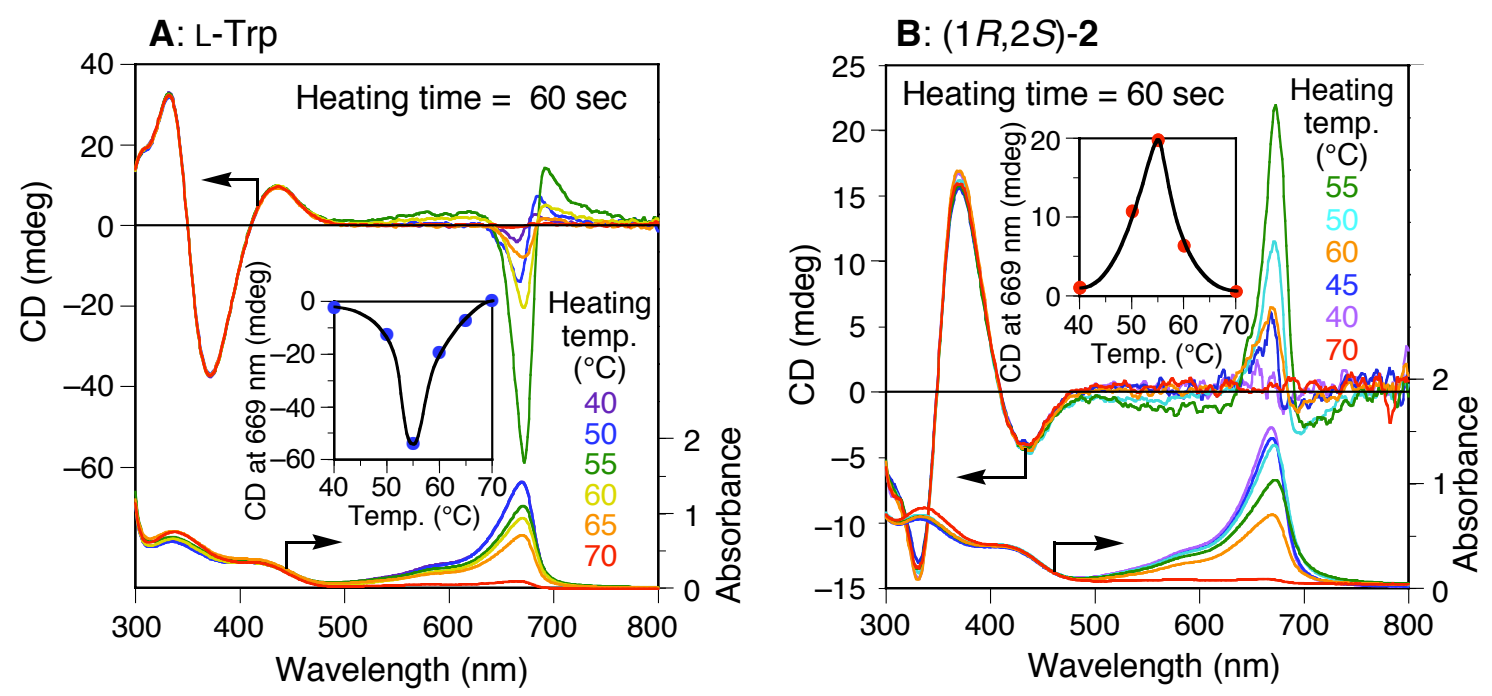

Figure S6. CD and absorption spectral changes in chiral J-aggregates of $\mathbf{O - 5}$ induced by the helical poly-1 assisted by L-Trp (A) and $(1 R, 2 S)-2$ (B) in acidic water after heating at various temperatures for $60 \mathrm{sec}$ followed by cooling in an ice bath for $60 \mathrm{sec}$. Inset shows the plots of CD intensity of chiral J-aggregates of O-5 at $669 \mathrm{~nm}$ verses the heating temperature. All spectra were measured in a $0.5-\mathrm{mm}$ quartz cell at room temperature (ca. $\left.24-26^{\circ} \mathrm{C}\right)$. [poly-1] $=1.0 \mathrm{mg} / \mathrm{mL},[\mathbf{O}-5] /[$ poly-1] $=0.1,[\mathrm{~L}-\mathrm{Trp}] /[$ poly$\mathbf{1}]=10,[(1 R, 2 S)-2] /[$ poly-1 $]=50$, and $\left[\mathrm{HClO}_{4}\right]=0.025(\mathrm{~A})$ and $0.20 \mathrm{M}(\mathrm{B})$. 
Effect of heating time on helical J-aggregates formation of $\mathbf{0 - 5}$ in the presence of helical poly-1 induced by L-Trp or $(1 R, 2 S)-2$
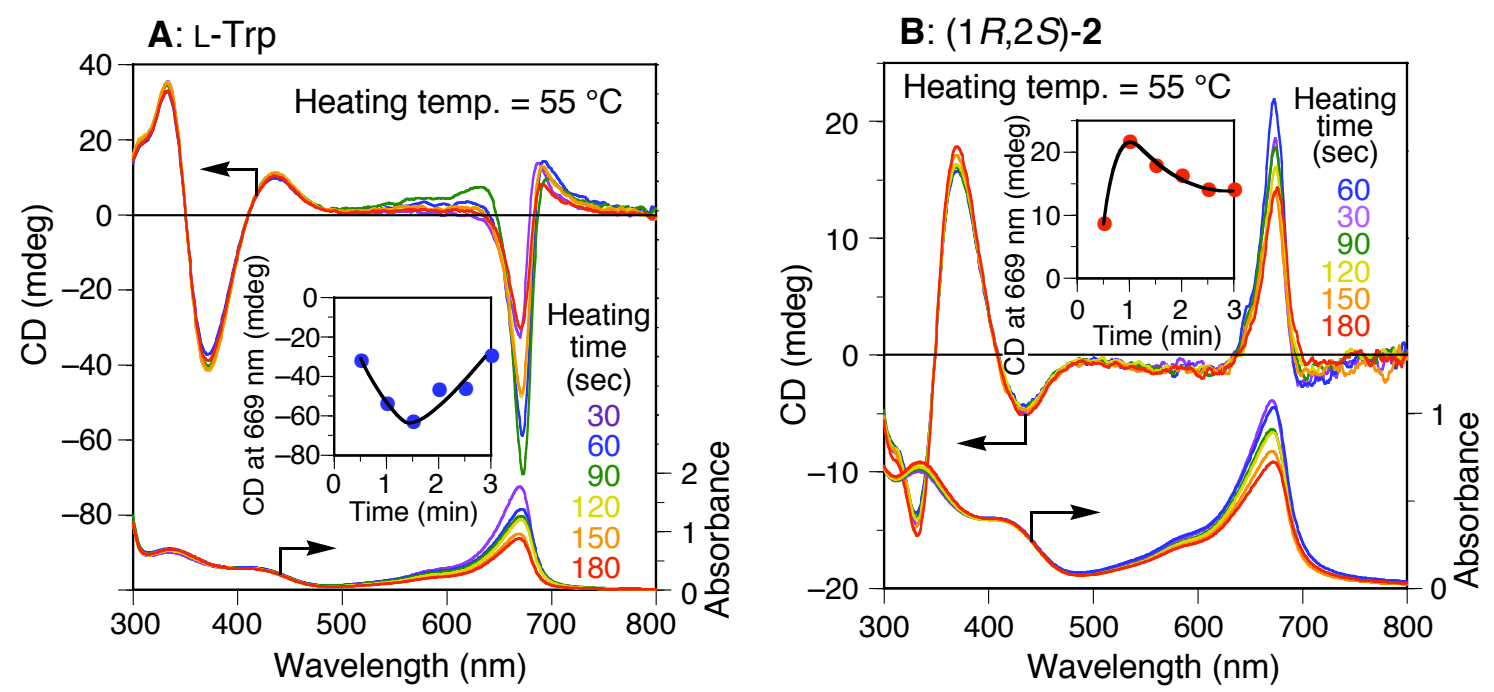

Figure S7. CD and absorption spectral changes in chiral J-aggregates of $\mathbf{O - 5}$ induced by the helical poly-1 assisted by L-Trp (A) and $(1 R, 2 S)-2$ (B) in acidic water after heating at $55^{\circ} \mathrm{C}$ for appropriate time followed by cooling in an ice bath for $60 \mathrm{sec}$. Inset shows the plots of CD intensity of chiral J-aggregates of O-5 at $669 \mathrm{~nm}$ verses the heating time. All spectra were measured in a $0.5-\mathrm{mm}$ quartz cell at room temperature (ca. $\left.24-25{ }^{\circ} \mathrm{C}\right) .[$ poly-1] $=1.0 \mathrm{mg} / \mathrm{mL},[\mathbf{O}-5] /[$ poly-1 $]=0.1,[\mathrm{~L}-\operatorname{Trp}] /[$ poly-1] $=10,[(1 R, 2 S)-$ 2] $/\left[\right.$ poly-1] $=50$, and $\left[\mathrm{HClO}_{4}\right]=0.025(\mathrm{~A})$ and $0.20 \mathrm{M}(\mathrm{B})$. 
Effect of $\mathrm{HClO}_{4}$ concentration on helical J-aggregates formation of $\mathbf{0 - 5}$ in the presence of helical poly-1 induced by L-Trp or $(1 R, 2 S)-2$

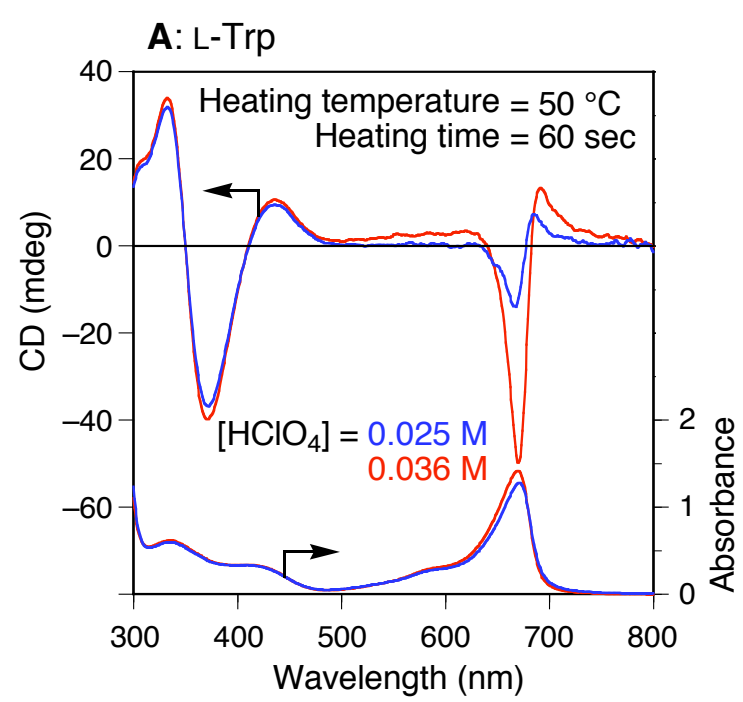

B: $(1 R, 2 S)-2$

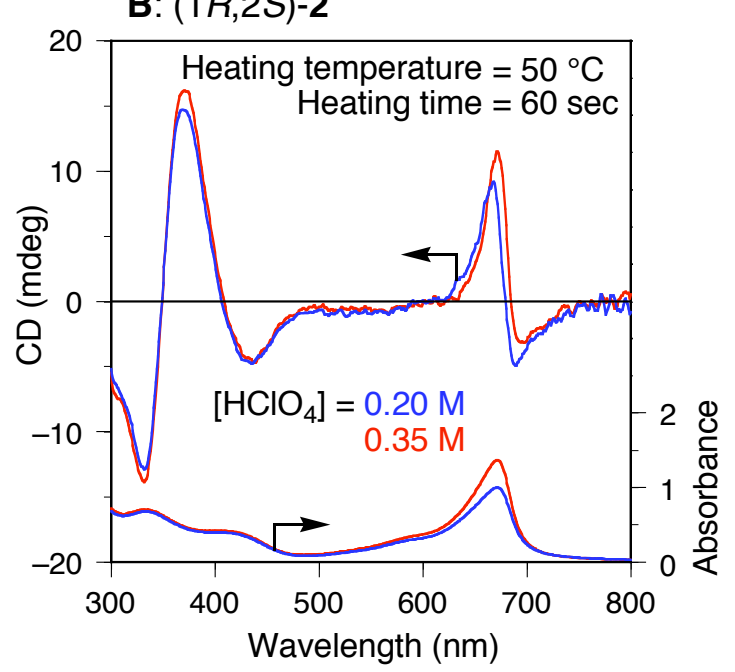

Figure S8. CD and absorption spectral changes in chiral J-aggregates of $\mathbf{0 - 5}$ induced by the helical poly-1 assisted by L-Trp $(\mathrm{A})$ and $(1 R, 2 S)-\mathbf{2}(\mathrm{B})$ in acidic water $\left(\left[\mathrm{HClO}_{4}\right]=\right.$ 0.025 or 0.20 (blue lines) and 0.036 or $0.35 \mathrm{M}$ (red lines)) after heating at $50{ }^{\circ} \mathrm{C}$ for 60 sec followed by cooling in an ice bath for $60 \mathrm{sec}$. All spectra were measured in a $0.5-$ $\mathrm{mm}$ quartz cell at room temperature $\left(\right.$ ca. $\left.26^{\circ} \mathrm{C}\right)$. [poly-1] $=1.0 \mathrm{mg} / \mathrm{mL},[\mathbf{O}-\mathbf{5}] /[$ poly-1] $=$ $0.1,[\mathrm{~L}-\operatorname{Trp}] /[$ poly-1] $=10,[(1 R, 2 S)-\operatorname{Trp}] /[$ poly-1] $=50$. 


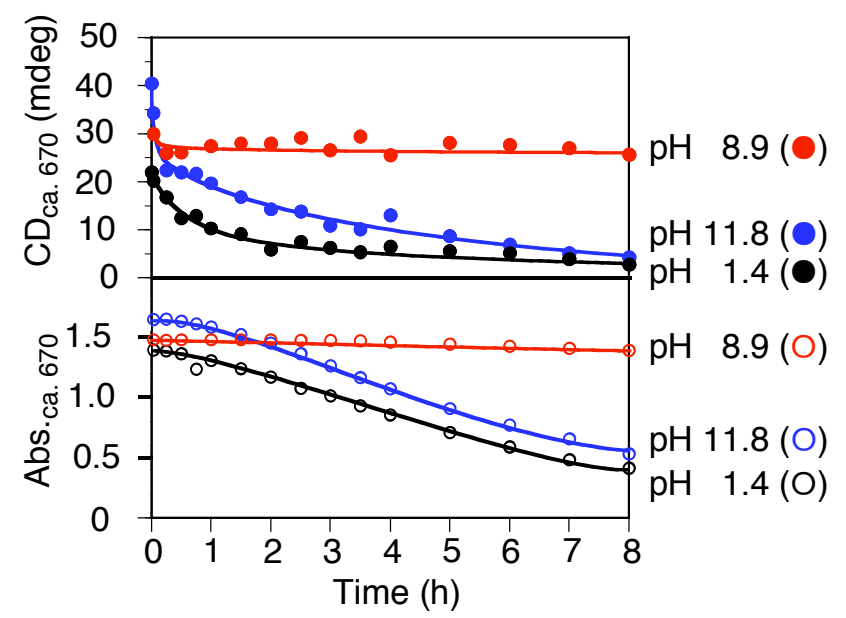

Figure 59. Time-dependent $\mathrm{CD}$ and absorbance intensity changes in chiral Jaggregates of $\mathbf{0 - 5}$ induced by the helical poly-1 assisted by $(1 R, 2 S)$-2 $([(1 R, 2 S)$ $2] /[$ poly-1] $=50$ ) at different $\mathrm{pH}$. $\mathrm{pH}$ was adjusted by adding $\mathrm{NaOH}$ aq. to the original acidic polymer solution at $\mathrm{pH}$ 1.4. Changes in the $\mathrm{CD}$ intensity (top) and absorbance (bottom) at ca. $670 \mathrm{~nm}$ were followed in a $0.5-\mathrm{mm}$ cell at $25^{\circ} \mathrm{C}$. [poly-1] $=1.0 \mathrm{mg} / \mathrm{mL}$, $[\mathbf{O}-5] /[$ poly-1] $=0.1$. 

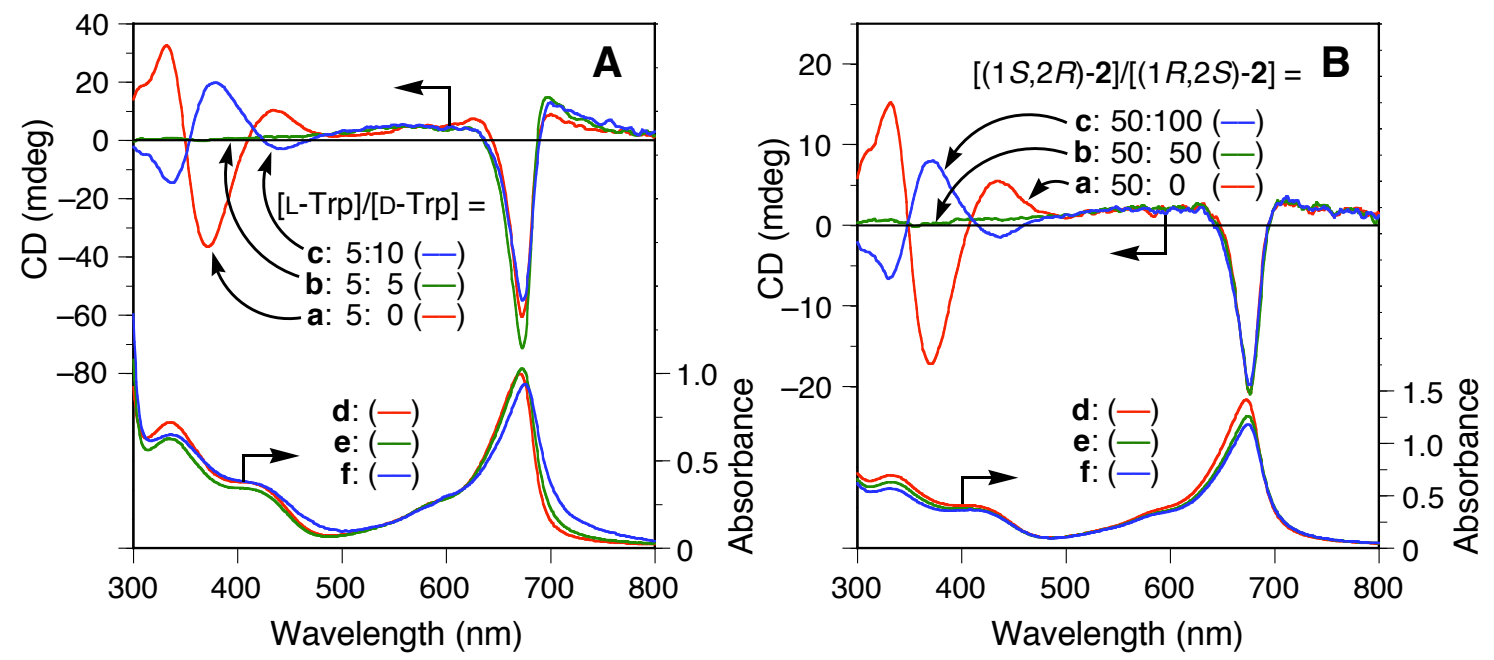

Figure S10. $\mathrm{CD}(\mathrm{a}-\mathrm{c})$ and absorption spectral changes $(\mathrm{d}-\mathrm{f})$ in chiral J-aggregates of 0-5 induced by the helical poly-1 assisted by L-Trp ([L-Trp]/[poly-1] = 10) (A) and $(1 S, 2 R)-2([(1 S, 2 R)-2] /[$ poly-1] $=50)$ in acidic water $(\mathrm{pH} 2.1$ (A) and $1.4(\mathrm{~B}))$ upon the addition of D-Trp ([D-Trp]/[L-Trp] = 0 (a and d, red lines), 1/1 (b and e, green lines), and $2 / 1$ (c and $\mathrm{f}$, blue lines)) (A) and $(1 R, 2 S)-2([(1 R, 2 S)-2] /[(1 S, 2 R)-2])=0$ (a and $\mathrm{d}$, red lines), 1/1 (b and e, green lines), and 2/1 (c and f, blue lines)) (B), respectively, at room temperature (ca. $24-25{ }^{\circ} \mathrm{C}$ ). All spectra were measured in a $0.5-\mathrm{mm}$ quartz cell. [poly-1 $]=1.0 \mathrm{mg} / \mathrm{mL},[\mathbf{O}-5] /[$ poly-1 $]=0.1$, and $\left[\mathrm{HClO}_{4}\right]=0.036(\mathrm{~A})$ and $0.20 \mathrm{M}(\mathrm{B})$. 

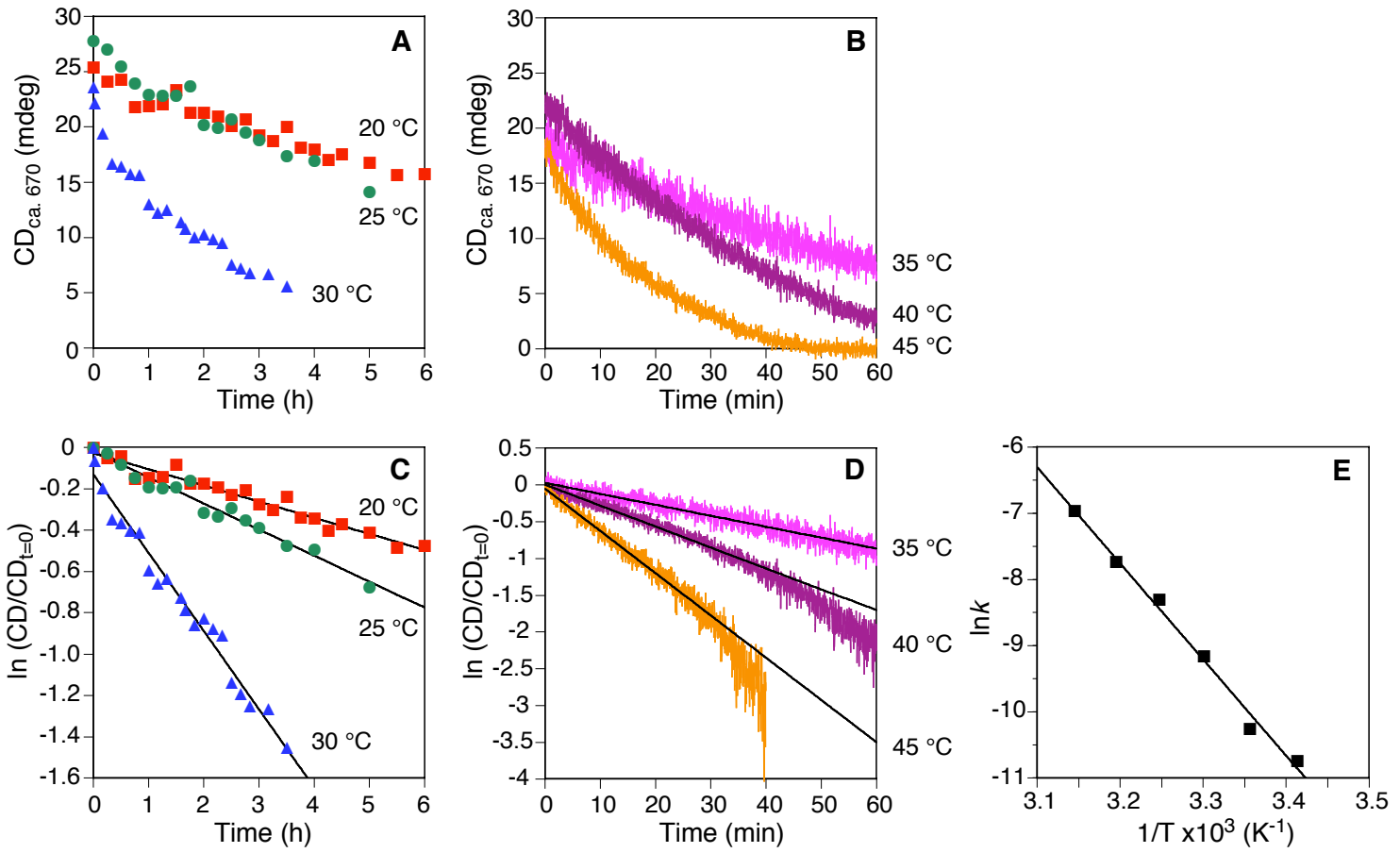

Figure S11. Racemization kinetics of chiral J-aggregates of $\mathbf{0 - 5}$ in water at $\mathrm{pH}$ 8.9. Changes in CD intensity at ca. $670 \mathrm{~nm}$ were followed in a 1.0-mm cell at 20, 25, 30 (A), 35,40 , and $45{ }^{\circ} \mathrm{C}(\mathrm{B})$. [poly-1] $=0.6 \mathrm{mg} / \mathrm{mL},[\mathbf{O}-5] /[$ poly-1] $=0.1,[(1 R, 2 S)-2] /[$ poly-1] $=50,[(1 R, 2 S)-2] /[(1 S, 2 R)-2]=1 / 1$. First-order plots of $\ln \left(\mathrm{CD} / \mathrm{CD}_{\mathrm{t}=0}\right)$ versus time at 20 , 25, 30 (C), 35, 40, and $45^{\circ} \mathrm{C}$ (D) and Arrhenius plot for $k$ (E). CD spectral changes were measured at appropriate time intervals at 20,25 , and $30{ }^{\circ} \mathrm{C}$ in (A) and the $\mathrm{CD}$ intensity changes at ca. $670 \mathrm{~nm}$ were then plotted against time, while the $\mathrm{CD}$ intensity changes at ca. $670 \mathrm{~nm}$ were directly followed at 35,40 , and $45^{\circ} \mathrm{C}$ in (B). 
Table S1. Racemization Kinetics Data for Chiral J-Aggregates of 0-5 in Water at $\mathrm{pH}$ 8.9.

\begin{tabular}{ccccc}
\hline $\begin{array}{c}\text { temperature } \\
\left({ }^{\circ} \mathrm{C}\right)\end{array}$ & $\begin{array}{r}k \times 10^{5} \\
\left(\mathrm{sec}^{-1}\right)\end{array}$ & $\begin{array}{c}\text { correlation } \\
\text { function }\end{array}$ & $\ln k$ & $\begin{array}{c}t_{1 / 2} \\
(\mathrm{~min})\end{array}$ \\
\hline 20 & 2.17 & 0.982 & -10.74 & 533 \\
25 & 3.50 & 0.973 & -10.26 & 330 \\
30 & 10.53 & 0.987 & -9.16 & 110 \\
35 & 24.56 & 0.950 & -8.31 & 47 \\
40 & 43.57 & 0.977 & -7.74 & 27 \\
45 & 94.28 & 0.981 & -6.97 & 12 \\
\hline
\end{tabular}

